\title{
A Theoretical Framework for Four Key Selected Determinants of Municipal Financial Performance
}

\author{
*Zwelihle Wiseman Nzuza \\ Department of Financial Accounting, Durban University of Technology, South Africa \\ Email: zwnzuza@gmail.com \\ Lawrence Mpele Lekhanya \\ Department of Public Management \& Economics, Durban University of Technology, South Africa \\ lekhanyam@yahoo.com or lawrencel@dut.ac.za
}

\section{Doi:10.5901/mjss.2014.v5n27p157}

\begin{abstract}
The aims of this study are twofold: to identify factors influencing the success of municipal financial performance and to design a model for key selected determinants of municipal financial performance. The study was cross-sectional and quantitative in nature and the questionnaire was an instrument used for data collection, and was distributed to only one municipality in the Kwa-Zulu Natal (KZN) Province. The sample consisted of 82 respondents, selected using a census sampling method. The proposed theoretical framework was designed following a literature review. The factors that fitted to the best were then selected as the basis for the proposed model. The results indicate a significant relationships of stock requisition ( $p=.000)$, procurement understanding $(p=.007)$, human transparency $(p=.000)$, and understanding of information communication technology (ICT) $(p=.000)$ with municipal financial performance. The study recommends that other researches to test and validate a proposed model could be conducted with large sample sizes.
\end{abstract}

Keywords: Stock control, procurement practices, human capital, information communication technology (ICT)

\section{Introduction}

Worldwide, municipal financial performance has become an issue of public attention and debate, and has been subjected to improvements, restructuring, rules, and regulations. This has been a considerable issue for many years and it has been also evident by many scholars. After evidence of the scholars, several developing and developed countries have taken steps to reform their municipal financial systems, but the operation is still shrouded by secrecy, inefficiency, exploitation, and undercutting. In all these cases, government has put huge amounts of resources with a purpose to improve the lives of the society through the municipal (Onyinkwa, 2013). In 1978, Corey provided a number of guidelines on financial decision making. In 2000, Faes, Matthyssens \& Vandernbempt as well as Arnod in 1999 established how to achieve a successful municipal finance. In 2005, Tella and Virolainen have identified motives for forming consortium municipal finance while Nollet and Beaulieu in 2005 have investigated the pros and corns of adopting consortium municipal finance. Other studies conducted include measurement of theory and practice as well as agency costs of the municipal operation (Karjalained, 2009). With reference to a Municipal Financial Management Act (MFMA), act No. 56 of 2003, the primary objective towards its promulgation was simply to ensure fairness, equitable, transparency, competitiveness and cost effectiveness in the control of municipal acquisitions (Watermeyer, 2011). According to Intaher \& Johanna (2012), the concept of municipal financial management refers to a decision making structure or process that monitors and controls the finances of local government, in order to achieve desired goals. The function of municipal finance also incorporates the acquisition of goods and services by a procuring entity using public funds. Apart from the actual acquisition of goods and services, the operation of municipal finance includes inbound and outbound logistics. Therefore, it is apparent that the municipalities must consider themselves as profit making organisations that are operating in a competitive marketing place. This is because, municipalities are also faced with an increased competition, desire for support from key constituencies, desire to increase the size and range of the working station, desire for new technologies, increased calls for accountability, a higher demand for quality by all the stakeholders involved, more responsibility for research, teaching, and greater emphasis on efficiency and effective procurement (Luby, 2013). Therefore, a challenge brought along with the development of a theoretical framework is, however, a largely unexplored 
area in the municipal context. This paper will focus on the development and testing of the four key selected determinants of municipal financial performance in order to provide an insight and improve the success of municipal finance.

\section{Aims and Objectives}

Aims: Firstly, this study seeks to identify factors influencing the success of the municipal financial performance. Lastly, the study seeks to design a model for four key selected determinants of municipal financial performance.

\subsection{Objectives}

- To examine factors affecting the success of financial performance;

- To test the significance associations of the examined factors with municipal financial performance; and

- To develop a theoretical framework for the key selected determinants of municipal financial performance.

\subsection{Study Hypotheses}

$\mathrm{H}_{1}$ : There is a significant relationship between stock control and financial performance.

$\mathrm{H}_{2}$ : There is a significant relationship between procurement practice and financial performance.

$\mathrm{H}_{3}$ : There is a significant relationship between human capital and financial performance.

$\mathrm{H}_{4}$ : There is a significant between ICT and financial performance.

\section{Theoretical Background}

The most model used to research into municipal financial performance is Municipal Financial Management Act (MFMA), act No. 56 of 2003 (Graves \& Dollery, 2009). The model emphasizes the prevention of unauthorized, irregular, and fruitless expenditures by local government authorities, which includes the safeguarding of local government resources. The MFMA model has indicated collective approaches, which take effectiveness, efficiency, economic viability, and transparency into account. This paper intends to validate the assertion mentioned in MFMA, but strongly believes that there are other factors influencing the municipal financial performance which also need to be taken into account, and has hence introduced a variety of variables to explore determinant factors.

\section{Literature Review}

The choice of stock control, procurement practices, human capital, and ICT can be justified by this argument from Hawkins \& Muir (2014) according to which future research surrounding knowledge management should offer valuable insights to matters of financial compliance in a public sector.

Stock control: Stock control is an approach to monitor or count inventory stock, and is likely to be performed by small, medium and large organizations that handle minor and large quantities of stock (Chiang, 2013). Another definition of stock control is provided by Hailing \& Guochao (2011) as a process in which the materials and parts carried in stock are regulated within pre-determined limits or set in accordance with the policy and procedures implemented or adopted by the organization. According to Kok \& Shang (2007), stock control is very much important to improve the organizational performance and its usefulness includes to reduce the level of errors pertaining to inventory records and physical count, e. g., stock loss or shrinkage, financial transaction errors (in inbound or outbound processes), and stock misplacement. They are many other reasons which make stock control very much important. Likewise, Mpwanya (2005) explained that stock control helps to ensure that inventory costs are reduced to a minimum level. Through stock control, municipalities can be able to eliminate inventory losses such as stock deterioration and improper distribution of customer orders (Singh \& Kumar, 2010). Minner \& Transchel (2010) explained that a good stock control can improve performance. A need for stock control also includes that of separating the stocks by its nature. Possibly, this may include the responsibility of setting out the levels of stock requirements for a specific time period (Bijulal, Venkateswaran \& Hemachandra, 2011). However, Liberatore (2011) revealed that stock control is a responsibility that needs to be performed by knowledgeable individuals and must be appointed by the organization. Nevertheless, practice of stock control requires an advanced technology such as stock keeping unit and bar-coding technologies of which they are foremost techniques in which stock control can be dealt with to reduce stock losses (Umakanta \& Chaitanya 2012). Of these technologies, bar-coding systems have gained a momentum and their usefulness includes that of reducing errors from internal control systems 
(Nassar \& Hegab, 2006; Nelson, 2010; Birkinshaw \& Heywood, 2010). However, it is imperative to make sure that the internal control systems are so strong (Umakanta \& Chaitanya, 2012). According to Huefner (2011), a strong internal control system can be categorized with good strategies that are able to improve stock purchase decisions, save time and money, increase efficiency, and improve customer service. To test the efficacy of stock control on financial performance, the following hypothesis was made:

H1: There is a significant relationship between stock control and financial performance.

Procurement practices: Procurement can be defined as a process or function to acquire and receiving stocks in the organization. This function should be effective in terms of preparing and processing the customer demands as well as the end receipt and approval of payments (Intaher \& Johanna, 2012). The concept of procurement practice refers to a transposition of theory into practical exercise whereas theory offers a vast body of analyses and prescriptions which constitute a primary reference for procurement practice (Pier \& Nicola, 2010). However, there are a lot of challenges that are still restraining the effectiveness and efficiency of the municipal procurement particularly in the developing countries (Intaher \& Johanna, 2012). These challenges resulted to a need for a consistent legislative framework that will give effect to government's procurement reform policy objectives. A 10 Point (Interim Strategies) Plan was then adopted and it design was aimed to impact positively on the organizational performance. On top of that, a Preferential Procurement Policy Framework Act (PPPFA), act No. 5 of 2000 was also promulgated to achieve best results on procurement practices. With reference to section 217 (1) of the PPPFA, the primary objective towards its promulgation was simply to ensure fairness, equitable, transparency, competitiveness and cost effectiveness in the control of municipal resources (Watermeyer, 2011).

Importantly, Atkinson \& Sapat (2012) and Larson (2009) have reported that procurement is a backbone of the municipalities in that it can open doors for the organization such as; getting new products, entering into a new market and being competitive, advancing technology, and gaining new skills. Nevertheless, commitment, supporting regulations, and reviewing of performance regularly are all considered as tools to improve procurement operations (Jovanovic \& Benkovic, 2012; Achua, 2011). Moreover, the preceding authors (Intaher \& Johanna, 2012; Jovanovic \& Benkovic, 2012; Achua, 2011; Garaca, 2011; Ruankaew \& Williams, 2013) have covered the areas of effectiveness and efficiency, and how well a municipal procurement can be implemented. But this study seeks to find out whether procurement does impact financial performance of the organization and how procurement fits into the development of a theoretical framework for four key selected determinants of municipal financial performance. To test the efficacy of procurement on financial performance, the following hypothesis was made:

H2: There is a significant relationship between procurement practice and financial performance.

Human capital: Human capital can be described as a combination of skills, knowledge, and experience by people or population viewed in terms of their value or cost to an organization (Nikbin, Saad, \& Ismai, 2010). Human capital plays an integral role to achieve desired goals of the organization (Gottschalk et al., 2010). A qualitative study by Naidoo \& Wu (2011) indicated a remarkable result from an interviewed manager who explained that "without human capital, there is no future in the organization". Similarly, authors (Nikbin et al., 2010; Naidoo \& Wu, 2011; Gottschalk \& Gudmundsen, 2010) have highlighted that human capital can improve the image of the organization. A study conducted by Nikbin et al. (2010) using a survey data collection from 102 managers in various public sectors of the northern region of Malaysia indicated that accessing the ability and trustworthy of individuals in very much important in the language of human capital. Failure to achieve desired goals can be a cause of poor evaluation and unavailability of resources which include talents, skills, commitments, and willingness of people to work (Aldehayyat \& Anchor, 2010). Correspondingly, a study conducted by Naidoo \& Wu (2011) using a mixed method in UK, US Australia, and New Zealand with questionnaires distributed to 570 mid-level international business managers indicated that a good organizational performance can be attained if dimensions of commitment, strategy, experience, and people's role factors are taken into account. In this respect, it is imperative for the executive management to give support that is necessary for employees to cope with difficulties during their work (Ramanigopal, 2012). Normally, the difficulties of attaining good performance require management support, and if not, an organization needs to hire experts. But since labour cost is too high, Pryor, Anderson, Toombs \& Humphreys (2007) promote that the workforce should assist each other by sharing ideas in their respective fields. To test the efficacy of human capital on financial performance, the following hypothesis was made:

H3: There is a significant relationship between human capital and financial performance.

Use of information communication technology (ICT): Due to a radical increase of financial challenges across the municipalities in the world, the regional and local governments are turning to use information communication technology (ICT) (Garaca, 2011). ICT can be described as a technical instrument to communicate information between the users (Allal-Cherif \& Babai, 2012). The importance of ICT is that it can help the organization to grow and remain competitive in the market (Juma, 2006). Even though the intention of ICT is to achieve economic growth, but a 
relationship between ICT and financial performance is still in question. For example, an empirical study conducted by Koellinger (2006) found a positive impact of ICT on production output, but not on financial performance while labour positively contributed on financial performance. There can be different attitudes of people in using ITC and can be a result of four factors such as: convinced user, forced user, frustrated user, and unconvinced user. However, ICT cannot function without commitment of staff (Allal-Cherif \& Babai, 2012). Therefore, it is of paramount important for the organization to motivate, educate and train or even force the members of staff to commit themselves in ICT (Garaca, 2011). But without measuring how ICT contributes to optimize performances, a resistance to change by staff cannot be overcome (Ruankaew \& Williams, 2013). On the other hand, Francesco (2013) mentioned that there are three main goals of ICT which include: to rationalize expenditure, reducing administrative confusion and costs, and fostering operational efficiency. Even though the literature makes it clear that ICT is so important, Ruankaew \& Williams (2013) exposed that the use of ICT is still new and there is a lot to be done to improve its efficiency in most of the organizations. Likewise, Garaca (2011) indicated that a retiring workforce in government sectors still need to be convinced of the usefulness of ICT for their business transactions.

In promoting the use of ICT for economic viability, the municipal authorities have implemented accessible communication infrastructures, which are to attract new business ideas, and above all, provide excellent services to its constituencies (Ruankaew \& Williams, 2013). The growing need of ICT in all government sectors becomes vital in the achievement of business goals. Although this sounds quit simple, it is much difficult to carry on. Therefore, ICT should be carried out by individuals with an ability and capacity to deal with its implications (Allal-Cherif \& Babai, 2012). To test the efficacy of ICT on financial performance, the following hypothesis was made:

H4: There is a significant between ICT and financial performance.

\section{Proposed Theoretical Framework}

Figure 1 shows that it is possible to model the municipal financial performance according to the four determinants factors: stock control; procurement practices; human capital; and information communication technology (ICT). When matching the four key selected determinants of municipal financial performance, it becomes clear that these four factors can be adequately modelled. This means that municipal financial performance is either driven by how stock is controlled, how management respond to procurement challenges, how workforce committee itself at work, and how ICT is being utilized effectively and efficiency by the municipality. Moreover, the development of a theoretical framework by this study formed the bases of this research. The purpose of the model is to demonstrate the significant relationships of the main research variables such as; stock control; procurement practices; human capital; and information communication technology with municipal financial performance. The analysis of the results is presented in figure 1 below.

Figure 1: Proposed theoretical framework for four determinants of municipal financial performance

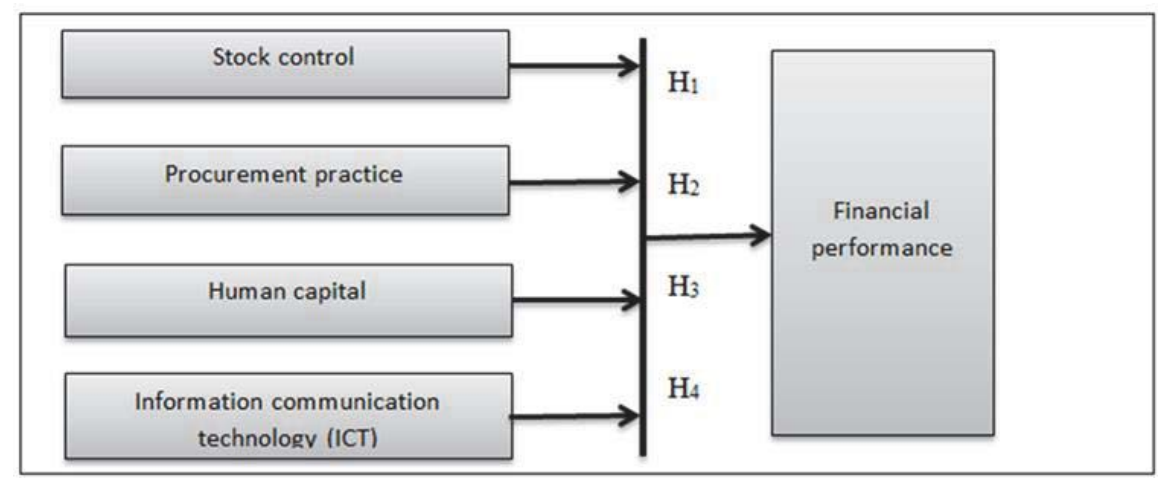

The main contribution of this theoretical framework is to reside in the fact that it provides more evidence on the suitability of municipal financial performance, instead of only relying on the MFMA model.

\section{Methodology}

This study was census, descriptive, cross-sectional and quantitative in nature. The methodology applied into this study 
was chosen for the convenience of the respondents.

Targeted population: The target population selected for investigation were the 82 members of staff from finance section of the South Africa municipality. The researcher targeted this population because of their relevance in financial control.

Research instrument: A questionnaire was used to collect data from 82 members of staff of the South Africa municipality. Questionnaire comprised a general section in which biographical information was formed and a section dealing with factors influencing the success of financial performance. A mix of nominal items in the questionnaire was employed in the biographical section. Apart from the demographics, all variables were measured using a 3 Point-type Likert scale. In total, the survey instrument comprised 16 main questions.

Data collection: The data collection for this study was self-administered. The overall response rate for the survey was high as the achieved response rate was $(94,25 \%)$. A total of 87 questionnaires were despatched (5 partial completed and 82 fully completed). Therefore, all 5 partial completed questionnaires were discarded resulting in a final sample of 82.

Data analysis: Descriptive and inferential statistics were used to analyse the quantitative data in the form of tables and graphs. Inferential techniques include the use of correlations and chi square test values; which are interpreted using the p-values. The data analysis was performed using the Statistical Package for Social Sciences (SPSS) version 21.0. The level of significance was set at $95 \%(p=0.05)$. The graphs and tables presented were extracted from Microsoft Excel to further clarify the findings.

Reliability and validity: The data analysis was performed using the Statistical Package for Social Sciences (SPSS). Reliability tests performed by this study were conclusive for all the questionnaire items (Cronbach's alpha >0.5). The survey's data also fully passed the validity test as all Likert scale items split into exactly five components. All tests were performed with a confidence level of 0.7 , thus concluding that the reliability of the study was acceptable.

\section{Research Findings}

Biographical data: Using frequencies and percentages for data presentation, this section describes the biographic profile of respondents, including education level and experience of 82 respondents. The detailed information is explained as follows:

Figure 2: Education level

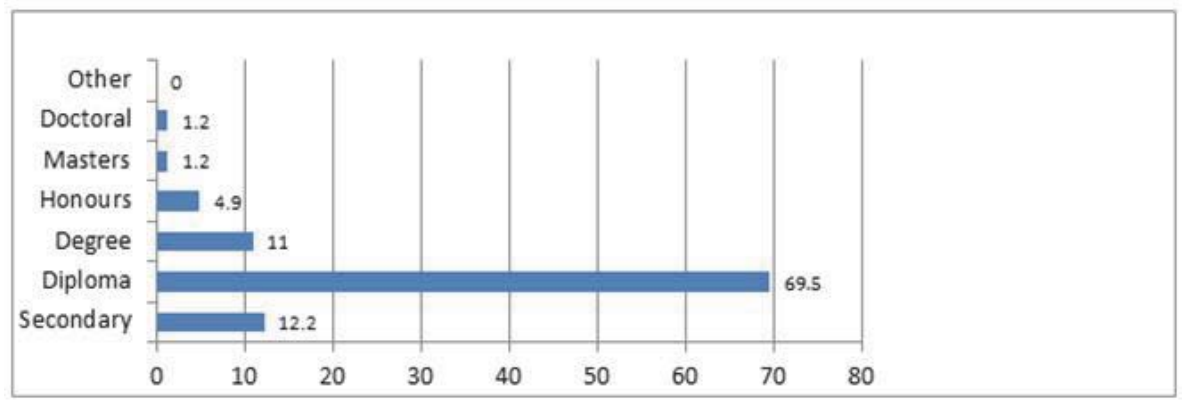

Of the 82 respondents in figure 2, $70 \%$ of the respondents had a diploma qualification, almost $12 \%$ had secondary education, $11 \%$ had a degree qualification, nearly $5 \%$ had honours qualification, about $1 \%$ had a master's qualification while about another $1 \%$ had a doctoral qualification, and $0 \%$ had other qualifications. This finding concludes that at least most of the respondents had a university background. But the respondents need to be encouraged to further their studies in order to improve their skills and talents. Education plays a significant role in improving the image and performance of the organization (National Treasury Republic of South Africa, 2001).

A t-test was conducted to see if there is any statistical significance or relationship between staff education and municipal financial performance. The results indicated that staff education and municipal financial performance have a strong significant relationship ( $\mathrm{t}=-11.085, \mathrm{df}=81, \mathrm{p}=.000$ ), concluding that the variables are strongly related to each other. Similar results were also found by Aldehayyat \& Anchor (2010) on the link between performance and staff education. 
Figure 3: Staff experience of service

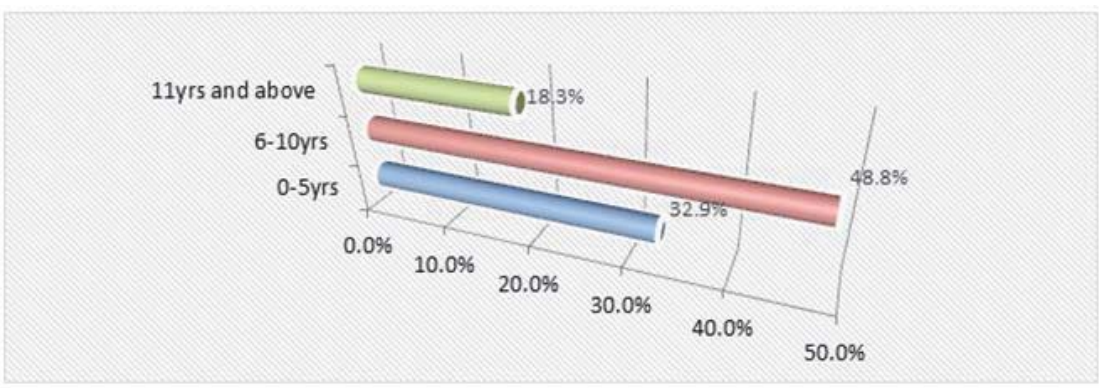

On the years of service, the survey established that the majority of the respondents (48.8\%) had worked for 6 to 10 years and above, $32.9 \%$ had worked for 0 to 5 years, and $18.3 \%$ of the respondents had worked for 11 years and above. This points to the fact that most of the respondents were adequately experienced since they had worked long enough to be conversant with operations of the municipality.

A t-test was conducted to see if there is any statistical significance or relationship between staff experience and municipal financial performance. The results indicated that staff experience and municipal financial performance have a strong significant relationship ( $\mathrm{t}=-10.244, \mathrm{df}=81, \mathrm{p}=.000)$, concluding that the variables are strongly related to each other. Similar results were revealed by a study conducted by Naidoo \& Wu (2011).

Figure 4: My organization is faced with financial crises

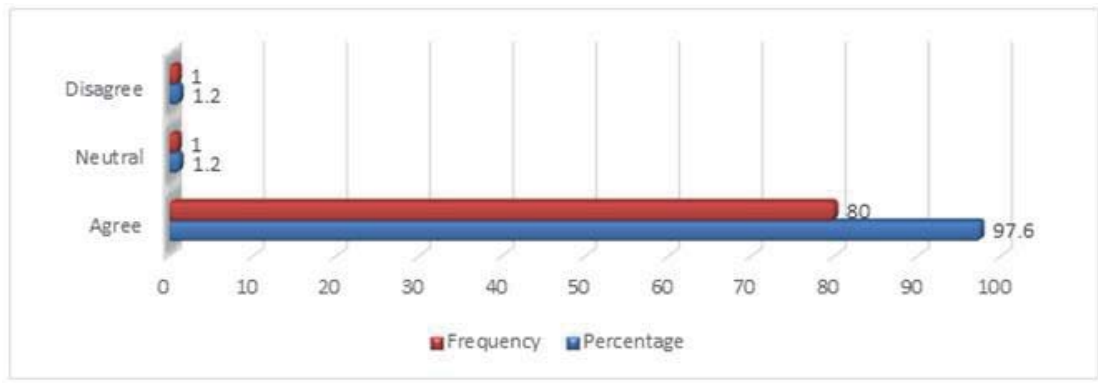

It can be inferred from figure 3 that most of the responses agreed with the statements. Basically, the respondents were asked to indicate their level of agreement on whether their organization does experience financial crises. The vast majority 80 (97.6 percent) of the respondents agreed that there are problems of finances that are experienced by their organization.

Table 1: Stock control

\begin{tabular}{|l|c|}
\hline Factors of stock control & Mean \\
\hline My organization if faced with expensive costs of making stock requisitions & 1.0488 \\
\hline My organization is faced with expensive costs of receiving stock orders & 1.0854 \\
\hline My organization is faced with expensive costs of maintenance & 1.0854 \\
\hline My organization experience understock situations & 2.4634 \\
\hline
\end{tabular}

Question: What is your opinion about the following statements in relation to costs of stock control? Scale: 1=agree, 2=neutral, $3=$ disagree

In table 1, statements 1, 2, and 3 represent a mean of close to 1, which is an "Agree" perception from the respondents. This indicates that most of the respondents agreed with these statements. Except for statement 4 which reflects a mean of closed to 2, which is a "Neutral perception from the respondents.

This indicates that the respondents were not sure whether the organization does experience understock situations. Therefore, the results emphasis that a municipality must improve a manner in which stock is controlled. Likewise, a study conducted by Kleemann, Glas \& Essig (2012) suggested that more effort should be placed on stock control as it has a 
significant relationship with financial control.

Table 2: Procurement practices

\begin{tabular}{|c|c|}
\hline Factors of procurement practices & Mean \\
\hline I fully understand procurement processes & 1.2561 \\
\hline Inbound logistic costs are too expensive & 1.2317 \\
\hline Outbound logistic costs are too expensive & 1.2073 \\
\hline
\end{tabular}

In table 2, the mean rankings reveal that the respondents fully understand procurement (mean rank of 1.26). Inbound logistic costs (mean rank of 1.23) are too expensive, and outbound logistic costs (mean rank of 1.21) are also expensive for the municipality.

Table 3: Human capital

\begin{tabular}{|l|c|}
\hline Factors of human capital & Mean \\
\hline Staffs are effective and efficiency in their jobs & 1.3049 \\
\hline Staffs are transparent & 1.4024 \\
\hline My organization have most qualified staffs & 2.7439 \\
\hline \\
Question: What is your opinion about the following statements in relation to human capital? Scale: 1=agree, 2=neutral, \\
3=disagree
\end{tabular}

Table 3 illustrates that statements 1 and 2 represent a mean of close to 1, which is an "Agree" perception from the respondents. This indicates that most of the respondents agreed with these statements. Except for statement 3 which reflects a mean of closed to 3 , which is a "Disagree" perception from the respondents. This indicates that the respondents disagreed that most of the staffs within their organization are adequately qualified. Therefore, the result emphases that the municipality needs to provide more training and developmental programs that are aimed to improve staffs skills in performing their job descriptions.

Table 4: Use of information communication technology (ICT)

\begin{tabular}{|l|c|}
\hline ICT factors & Mean \\
\hline ICT is applicable on financial decisions & 1.4756 \\
\hline ICT provides enough financial information & 1.4756 \\
\hline I fully understand ICT & 1.6220 \\
\hline
\end{tabular}

Question: What is your opinion about the following statements in relation to ICT? Scale: 1=agree, 2=neutral, $3=$ disagree

As shown in table 4, statements 1 and 2 represent a mean of close to 1, which is an "Agree" perception from the respondents. This indicates that most of the respondents agreed with these statements. Except for statement 3 which reflects a mean of closed to 2, which is a "Neutral" perception from the respondents. This indicates that the respondents doubted their understanding of ICT, concluding that even though the ICT provides them with useful information but they do not have adequate understanding which might result in poor financial decision and failure to use information in a right way. Therefore, these results are similar to that of Garaca (2011) who found that the use of ICT is a challenge in the most municipalities.

Structural model assessment and discussion: A total of 82 samples were used to examine the factors influencing municipal financial performance and to test the significance relationship of these factors with municipal financial performance in order to provide validity of the proposed research model (Fig. 5 and Table 5). The assessment of the model to validate model fitness, which is a measure of the validity of the model, and statistical testing (t-test), is used to explain the research hypothesis and conclusion thereof. 
Figure 5: Results of the proposed theoretical framework

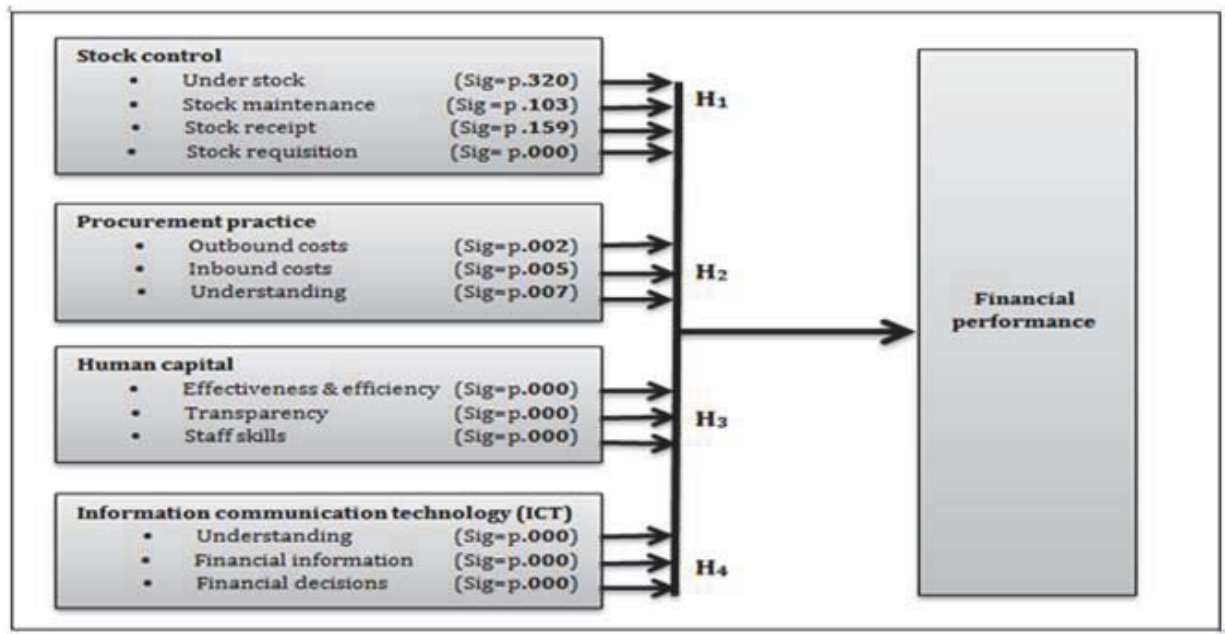

Table 5: Summary of paired samples t-test

\begin{tabular}{|l|c|c|c|}
\hline Model variables and financial performance & $\mathbf{t}$ & $\mathbf{d f}$ & Sig. (2-tailed) \\
\hline Pair 1 Understanding stock & -1.000 & 81 & .320 \\
\hline Pair 2 Stock maintenance & -1.650 & 81 & .103 \\
\hline Pair 3 Stock receipt & -1.423 & 81 & .159 \\
\hline Pair 4 Stock requisition & -13.893 & 81 & .000 \\
\hline Pair 5 Outbound costs & -3.160 & 81 & .002 \\
\hline Pair 6 Inbound costs & -2.862 & 81 & .005 \\
\hline Pair 7 Understanding procurement & -2.750 & 81 & .007 \\
\hline Pair 8 Staff effectiveness \& efficiency & -3.639 & 81 & .000 \\
\hline Pair 9 Staff transparency & -3.881 & 81 & .000 \\
\hline Pair 10 Staff skills & -24.231 & 81 & .000 \\
\hline Pair 11 Understanding ICT & -5.154 & 81 & .000 \\
\hline Pair 12 Financial information by ICT & -4.952 & 81 & .000 \\
\hline Pair 13 Financial decisions by ICT & -5.968 & 81 & .000 \\
\hline
\end{tabular}

T-test Sig. (2-tailed) is significant at $p=0.05$ or $>0.05$ levels

$\mathrm{H}_{1}$ : There is a significant relationship between stock control and financial performance

A t-test was conducted on the stock control factors that influence municipal financial performance. The tested variables and results under this hypothesis include: under stock $(t=-1.000, d f=81, p=.320)$, stock maintenance ( $t=-1.650$, $d f=81, p=.103)$, stock receipt $(t=-1.423, d f=81, p=.159$, and stock requisition $(t=-13.893, d f=81, p=.000)$. However, the results indicated that stock requisition has a strong significant relationship with financial performance of the municipality.

$\mathrm{H}_{2}$ : There is a significant relationship between procurement practice and financial performance

A t-test was conducted on the procurement practice factors that influence municipal financial performance. The tested variables and results under this hypothesis include: outbound costs ( $t=-3.160, d f=81, p=.002)$, inbound costs ( $t=-$ 2.862, $d f=81, p=.005)$, and understanding ( $t=-2.750, d f=81, p=.007)$. However, the results indicated that outbound costs, inbound costs, and understanding of procurement have a strong significant relationship with financial performance of the municipality.

$\mathrm{H}_{3}$ : There is a significant relationship between human capital and financial performance

A t-test was conducted on the human capital factors that influence municipal financial performance. The tested variables and results under this hypothesis include: effectiveness \& efficiency $(t=-3.639, d f=81, p=.000)$, transparency ( $t=-$ $3.881, \mathrm{df}=81, \mathrm{p}=.000)$, and staff skills $(\mathrm{t}=-24.231, \mathrm{df}=81, \mathrm{p}=.000)$. However, the results indicated that staffs effectiveness and efficiency at work, their transparency and skills have a strong significant relationship with financial performance of the municipality.

$\mathrm{H}_{4}$ : There is a significant between ICT and financial performance

A t-test was conducted on the ICT factors that influence municipal financial performance. The tested variables and 
results under this hypothesis include: understanding ( $t=-5.154, d f=81, p=.000)$, financial information $(t-4.952, d f=81$, $\mathrm{p}=.000$ ), and financial decisions ( $\mathrm{t}=-5.968, \mathrm{df}=81, \mathrm{p}=.000$ ). However, the results indicated that staffs understanding of ICT, the ability of ICT to provide good financial information and financial decisions have a strong significant relationship with financial performance of the municipality.

In this paper, a review of stock control; procurement practices; human capital; and information communication technology (ICT) was conducted followed by a review of the municipal financial management in general. Interestingly, the match of these factors helped to form a theoretical framework for four key selected determinants of municipal financial performance. This framework is also recommended to be used in any other research field with an intention to gage on the factors affecting the success of financial performance.

Bivariate Correlations: The bivariate correlations were performed in this study. All significant relationships are indicated by $a *$ or **.

Table 6: Correlations

\begin{tabular}{|c|c|c|c|c|c|c|c|c|}
\hline & Qualification & Experience & $\begin{array}{c}\text { Qualified } \\
\text { staff }\end{array}$ & $\begin{array}{c}\text { Effectiveness } \\
\& \\
\text { efficiency }\end{array}$ & Staff skills & $\begin{array}{c}\mathrm{ICT} \\
\text { understanding }\end{array}$ & $\begin{array}{l}\text { Financial } \\
\text { information } \\
\text { by ICT }\end{array}$ & $\begin{array}{c}\text { ICT } \\
\text { application }\end{array}$ \\
\hline \multirow{3}{*}{$\begin{array}{l}\text { Qualification Pearson Correlation } \\
\text { Sig. (2-tailed) } \\
\text { N }\end{array}$} & 1 & $.394^{* *}$ & $.497^{* *}$ & $.611^{* *}$ & $.462^{* *}$ & $.322^{* *}$ & $.309^{* *}$ & $.315^{* *}$ \\
\hline & & .000 & .000 & .000 & .000 & .003 & .005 & .004 \\
\hline & 82 & 82 & 82 & 82 & 82 & 82 & 82 & 82 \\
\hline Experience Pearson Correlation & $-.394^{* *}$ & 1 & $.286^{* *}$ & $.267^{*}$ & .032 & .201 & .171 & .191 \\
\hline Sig. (2-tailed) & .000 & & .009 & .015 & .774 & .070 & .124 & .086 \\
\hline $\mathrm{N}$ & 82 & 82 & 82 & 82 & 82 & 82 & 82 & 82 \\
\hline \multirow{3}{*}{$\begin{array}{l}\text { Financial Pearson Correlation } \\
\text { performance Sig. (2-tailed) } \\
\text { N }\end{array}$} & -.209 & .103 & $.357^{\star *}$ & .076 & .020 & .104 & .100 & .066 \\
\hline & .059 & .359 & .001 & .498 & .859 & .351 & .371 & .559 \\
\hline & 82 & 82 & 82 & 82 & 82 & 82 & 82 & 82 \\
\hline
\end{tabular}

**. Correlation is significant at the 0.01 level (2-tailed). * . Correlation is significant at the 0.05 level (2-tailed)

Table 6 shows that the variables with positive relationships have $a *$ or **. $A$ * shows that the variables are correlated and significant at the 0.05 level (2-tailed), and ${ }^{* *}$ shows that the variables are correlated at the 0.01 level (2-tailed). This type of test was conducted because there were more than one group involved; therefore, bivariate ( 2 tailed) analysis should be used to demonstrate whether there are direct or inverse proportional relationships between the research variables (Malhotra \& Birks, 2011).

Theoretical contribution: The development of a theoretical framework for four key selected determinants of municipal financial performance shows that stock control, procurement practices, human capital, and ICT are the most contributing factors on the success or failure of municipal financial performance. These factors also have a positive correlation with municipal financial performance.

\section{Limitations of the Study}

This study did not cover all municipalities and was confined to only one department, with specific reference to the KwaZulu Natal (KZN) Province. Therefore, the results of the study cannot be generalized to all municipalities of South Africa. Due to the complexity of the South African municipalities, it was difficult to research every sector in every province. Further research needs to include more municipalities, with a large sample because this study did not cover those areas.

\section{Conclusion}

The purpose of this study was to design and test a theoretical framework for four key selected determinants of municipal financial performance. The findings of the study are similar in many respects to studies in other countries (United State, Australia, New Zealand, Malaysia, Nigeria, Tanzania and Malawi). The study therefore adds to the body of knowledge in developing a new theoretical framework for four determinants of municipal financial performance. The results of the research show the importance of paying more attention on stock requisition, procurement processes, human capital (i.e., education, experience, skills, efforts and training), and on the implications of ICT. The study also revealed that the four determinants: stock control, procurement practices, human capital, and ICT have positive and strong significant relationships with municipal financial performance. This study recommends that similar researches to test and validate a 
proposed theoretical framework could be conducted with large sample sizes even in other countries outside South Africa.

\section{References}

Achua, J. K. (2011). Anti-corruption in public procurement in Nigeria: Challenges and competency strategies. Journal of public procurement, 11(3): 323.

Aldehayyat, J. S. \& Anchor, J. R. (2010). Strategic planning implementation and creation of value in the firm. Strategic change, 19(3): 163.

Allal-Cherif, O. \& Babai, M. Z. (2012). Do electronic marketplaces improve procurement performance?: Supply chain forum. International journal, 13(3): 40.

Atkinson, C. L. \& Sapat, A. K. (2012). After Katrina: comparisons of post disaster public procurement approaches and outcomes in the New Orleans area. Journal of public procurement, 12(3):360-363.

Bijulal, D., Venkateswaran, J. \& Hemachandra. N. (2011). Service levels, system cost and stability of production inventory control systems. International journal of production research, 49(23): 7085-7088.

Birkinshaw, J. \& Heywood, S. (2010). Putting organizational complexity in its place. McKinsey quarterly, 3(6): 228.

Chiang, C. (2013). A note on periodic review inventory models with stochastic supplier's visit intervals and fixed ordering cost. International journal of production economics, 146(2): 662.

Francesco, G. (2013). A model to measure e-procurement impacts on organizational performance. Journal of public procurement, 13(2): 216-217.

Garaca, Z. (2011). Factors related to the intended use of ERP systems: Management. Journal of contemporary management issues, 16(2): 23-24.

Gottschalk, P. \& Gudmundsen, Y. S. (2010). An empirical study of intelligence strategy implementation. International journal of police science \& management, 12(1): 55.

Graves, N. \& Dollery, B. (2009). Local government reform in South Africa: An analysis of financial management legislative compliance by municipalities. Public administration \& development, 29(5), 387-392.

Hailing, D. \& Guochao, J. (2011). Limit distribution of inventory level of perishable inventory model. Mathematical problems in engineering, 1(1): 1-2.

Hawkins, T. G. \& Muir, W. A. (2014). An exploration of knowledge-based factors affecting procurement compliance. Journal of public procurement, 14(1): 2-24.

Huefner, R. J. (2011). Internal control weaknesses in local government. CPA journal, 87(7), 26.

Huque, A. S. \& Vyas, L. (2008). Expectations and performance: assessment of public service training in Hong Kong. International Journal of human resource management, 19(1): 188.

Intaher, M. A. \& Johanna, A. B. (2012). Procurement challenges in the South African public sector. Journal of transport and supply chain management, 6(1): 242-255.

Juma, M. W. (2006). The impact of ICT adoption on financial performance of commercial banks in Kenya.From<http://erepository.uonbi.ac.ke/bitstream/handle/11295/13885/ABSTRACT.pdfsequenc =3 (Retrieved 10 June 2014).

Jovanovic, P. \& Benkovic, S. (2012). Improvements in organizing public procurement at the local self-government level in Serbia. Management, 64(5), 25-27.

Karjalained, K. (2009). Challenges of purchasing centralization-empirical evidence from public procurement. Available from: http://epub.lib.aalto.fi/pdf/diss/a344.pdf [Accessed 4 June 2014].

Kleemann, F. C., Glas, A, \& Essig, M. (2012). Public procurement through performance based logistics: conceptual underpinnings and empirical insights. Journal of public procurement, 12(2): 152-161.

Koellinger, P. (2006). Impact of ICT on corporate performance, productivity and employment dynamics. From <http://www.empirica.com /themen/ebusiness/documents/TR_2006_ICTImpact_I.pdf (Retrieved 10 June 2014).

Kok, A. G.\& Shang, K. H. (2007). Inspection and replenishment policies for systems with inventory record inaccuracy. Manufacturing \& service operations management, 9(2): 185.

Larson, P. D. (2009). Public vs. Private sector perspectives on supply chain management. Journal of public procurement, $9(2): 222$.

Liberatore, M. J. (1979). Using MRP and EOQ/safety stock for raw materials inventory control: Discussion and case study. Interfaces, 9(2): 2.

Luby, M. J. (2013). The impact of the great recession on the financial management practices of state and local governments: part I. Journal of public budgeting, accounting \&financial management, 25(1): 160.

Malhotra, N. K. \& Birks, D. F. (2006). Marketing research an applied approach. (2th ed). London: Prentice Hall, Inc.

Minner, S. \& Transchel, S. (2010). Periodic review inventory-control for perishable products underservice level constraints. OR Spectrum, 32(4): 978-980.

Mpwanya, M. F. (2005). Inventory management as determinant for improvement of customer service. M. Com, University of Pretoria. From <http://web.up.ac.za/default.asp?ipkCategorylD=17735\&subid=17735\&ipookid=1 (Retrieved 24 July 2013).

Naidoo, V. \& Wu, T. (2011). Marketing strategy implementation in higher education: Amixed approach for model development and testing. Journal of marketing management, 27(11): 112.

Nassar, K. M. \& Hegab, M. 2006. Developing a complexity measure for project schedules. Journal of construction engineering \& management, 132(6): 555 
National treasury republic of South Africa, (2001). From <http://www.treasury.gov.za/legislation/pfma/regulations/gazette_22141.pdf (Retrieved 24 January 2014).

Nelson, C. M. (2010). Complex job structure and intelligence: a research proposal. Journal of the Utah academy of sciences, arts \& letters, 87(1): 71-72.

Nikbin, D., Saad, N. N. \& Ismail, I. (2010). The relationship between internal marketing and implementation of strategic orientations in Malaysian service industry. International journal of business \& management science, 3(1): 17.

Onyinkwa, J. (2013). Factors influencing compliance to procurement regulations in public secondary schools in Kenya: a case of Nyamache District, Kisll County. Interdisciplinary journal of contemporary research in business, 5(1): 561.

Pier, A. M. \& Nicola, D. (2010). The economics of procurement contract awarding: problems and solutions in theory and practice. Journal of public procurement, 10(1): 94-95.

Pryor, M. G., Anderson, D., Toombs, L. A. \& Humphreys, J. H. (2007). Strategic Implementation as a Core Competency. Journal of management research (09725814), 7(1): 6-9.

Ramanigopal, C. (2012). Knowledge Management Strategies for Successful Implementation in Aerospace Industry. Advances in management, 5(12): 19-20.

Ruankaew, T. \& Williams, P. (2013). The impact of inventory inaccuracy in the food manufacturing industry: A case study. Business management dynamics, 2(10): 27.

Singh, S. R. \& Kumar, V. (2010). Two Storage inventory model for deteriorating items with exponential demand and shortages. International transactions in applied sciences, 2(4): 771.

Umakanta, M. \& Chaitanya, K. T. (2012). An EOQ model for time dependent weibull deterioration with linear demand and shortages. Scientific journal of logistics, 8(2), 124.

Watermeyer, R. B. (2011). Public procurement regulation in Africa conference: Regulating public procurement in Southern Africa through international and national standards. From <www.ssinc.co.za/Files/Doc/RBWPapers/T3-18.pdf (Retrieved 25 January2014). 